\title{
Redescription of Moenkhausia melogramma (Characiformes: Characidae), a poorly known tetra from a the western Amazon basin
}

Correspondence:

Isabel M. Soares bioimsoares@gmail.com

Submitted April 8, 2020

Accepted June 29, 2020

by Carlos DoNascimento

Epub September 04, 2020

Online version ISSN 1982-0224

Print version ISSN 1679-6225

Neotrop. Ichthyol

vol. 18, no. 3, Maringá 2020

\author{
${ }^{\oplus}$ Isabel M. Soares ${ }^{1},{ }^{\oplus}$ Rafaela P. Ota ${ }^{2},{ }^{\oplus}$ Flávio C. T. Lima ${ }^{3}$ and \\ ${ }^{\bullet}$ Ricardo C. Benine ${ }^{1}$
}

Moenkhausia melogramma is herein redescribed, based on the examination of the holotype plus additional specimens from the western Amazon basin in Brazil, Colombia, Peru, and Ecuador. Moenkhausia melogramma shares with M. collettii, M. conspicua, M. copei, M. venerei, and $M$. flava a broad dark longitudinal stripe across the eye, and a well-defined dark stripe on the anal-fin base. It can be promptly distinguished from these species by having two humeral blotches. Additionally, we provide comments on the putative relationships of Moenkhausia melogramma with the aforementioned congeners and the Hemigrammus lunatus species-group.

Keywords: Bony hooks, Color pattern, Hemigrammus machadoi, Moenkhausia collettii species-group, Taxonomy.

1 Programa de Pós-Graduação em Ciências Biológicas (Zoologia), Laboratório de Ictiologia, Setor de Zoologia, Instituto de Biociências, Universidade Estadual Paulista "Júlio de Mesquita Filho", Rua Professor Walter Maurício Correia, Distrito de Rubião Júnior, 18618-681 Botucatu, SP, Brazil. (IMS) bioimsoares@gmail.com (corresponding author), (RCB) ricardo.benine@unesp.br.

2 Programa de Pós-Graduação em Biologia de Água Doce e Pesca Interior, Instituto Nacional de Pesquisas da Amazônia, Av. André Araújo, 2936, Petrópolis, 69060-001 Manaus, AM, Brazil. (RPO) rafaelapota@gmail.com.

3 Museu de Zoologia da Universidade Estadual de Campinas “Adão José Cardoso”, Caixa Postal 6109, 13083-863 Campinas, SP, Brazil. (FCTL) fctlima@gmail.com. 
Moenkhausia melogramma é redescrita com base no exame do holótipo e exemplares adicionais da bacia amazônica ocidental no Brasil, Colômbia, Peru e Equador. Moenkhausia melogramma compartilha com M. collettii, M. conspicua, M. copei, $M$. venerei e $M$. flava a presença de uma faixa larga longitudinal escura que atravessa os olhos e uma linha escura bem definida na base da nadadeira anal. Ela pode ser prontamente distinguida dessas espécies por ter duas manchas umerais. Adicionalmente, fornecemos comentários sobre as possíveis relações filogenéticas de Moenkhausia melogramma com as congêneres supramencionadas e com o grupo de espécies Hemigrammus lunatus.

Palavras-chave: Ganchos ósseos, Grupo de espécies Moenkhausia collettii, Hemigrammus machadoi, Padrão de colorido, Taxonomia.

\section{INTRODUCTION}

Moenkhausia Eigenmann, 1903 is one of the most species-rich genus in Characidae with 93 valid species (Soares, Benine, 2019; Soares et al., 2019), behind only of Hyphessobrycon Durbin in Eigenmann, 1908 (158 spp.) and Astyanax Baird, Girard, 1854 (126 spp.) (Fricke et al., 2020; Terán et al., 2020), and widely distributed in the cis-Andean basins of South America. Not surprisingly, the latest hypotheses of phylogenetic relationships recovered Moenkhausia as paraphyletic, using morphological (Mirande, 2010), molecular (Oliveira et al., 2011; Mariguela et al., 2013) or combined morphological and molecular data (Mirande, 2019). Therefore, the genus remains diagnosed by a combination of characters that includes two series of teeth on premaxilla, five teeth in the inner tooth series of the premaxilla, a complete lateral line, and caudal fin partly covered by small scales (Eigenmann, 1917). Nonetheless, the lateral line completeness has been confirmed as a highly homoplastic character (Mirande, 2010, 2019), a suspected condition that has prompted some authors to assign species having incompletely pored lateral line in Moenkhausia (i.e., M. pyrophthalma Costa, 1994; M. diktyota Lima, Toledo-Piza, 2001; M. cosmops Lima, Britski, Machado, 2007; M. forestii Benine, Mariguela, Oliveira, 2009, and M. uirapuru Ohara, Lima, 2015).

Moenkhausia melogrammus was described by Eigenmann (1908) based on a single specimen from upper Amazon basin in Tabatinga, Amazonas State, Brazil (MCZ 20825), which was collected during the Thayer Expedition and was only described 43 years later (Fig. 1). The name of the species was later amended to M. melogramma by Eigenmann (1910). The original description only mentioned the number of fin rays, the misalignment of the third premaxillary tooth of the outer row in relation to the other teeth, and general color pattern, characterized by the absence of blotches, presence of a faint stripe along mid-body, and presence of a dark stripe along the anal-fin base.

Later, Eigenmann (1917: 78-79) provided a more detailed description of the species, including a retouched picture of the holotype (pl. 6, fig. 1) but, once again, solely based on the holotype. Géry (1977) proposed an artificial key to Moenkhausia and divided the genus into three groups of species - M. lepidura, M. grandisquamis, and M. chrysargyrea - according to the shape of body, number of scales above and below lateral line). 
Géry (1977) placed M. melogramma within the M. grandisquamis group, composed by deep-bodied species, with five scale rows above and three or four rows below lateral line, whereas M. collettii (Steindachner, 1882) and M. copei (Steindachner, 1882) were allocated in the M. lepidura group, composed by small species with body depth usually more than 2.75 in the standard length. Since then, other than citations in checklists and catalogs (which did not add any additional information on the species) there was little mention for the species in the literature.

Moenkhausia melogramma was commonly misidentified as $M$. collettii or even as Hemigrammus lunatus Durbin, 1918 in fish collections, since these species are very similar in color and shape. In this context, our main goal is to redescribe M. melogramma, based on the examination of the holotype and additional material, including topotypes, identified during examination of extensive material by the first author. Additionally, we updated the geographic distribution of $M$. melogramma, and discussed the putative relationships between species sharing a broad dark longitudinal stripe across the eye and a dark longitudinal stripe on the anal-fin base.

\section{MATERIAL AND METHODS}

Counts and measurements were taken on the left side of specimens whenever possible, using a digital caliper with precision of $0.1 \mathrm{~mm}$, and the methodology follow Fink, Weitzman (1974) and Menezes, Weitzman (1990), with addition of head depth, which was measured at the vertical through the tip of the supraoccipital spine. Measurements are given as percentage of standard length (SL), except subunits of head that are given as percentage of head length (HL). Counts of vertebrae, supraneurals, procurrent caudal-fin rays, and unbranched rays of the anal fin were taken from cleared and double-stained specimens (c\&s) prepared according to Taylor, Van Dyke (1985). Total vertebral counts include the Weberian apparatus, counted as four elements, and the fused PU1+U1 counted as a single vertebral element. The gill raker at the junction of the ceratobranchial and the epibranchial is included in the count of gill rakers of the lower limb.

Counts and measurements of holotype were taken by the last author (RCB), while vertebral, supraneurals, and procurrent caudal-fin rays counts were taken from radiograph of the holotype, available on the website of the Museum of Comparative Zoology (MCZ). Counts are followed by the total number of examined specimens, which is given first, followed by the number of cleared and stained individuals (if any); asterisks indicate values for the holotype. The map was prepared using QGis 3.4.6 Madeira (QGIS Geographic Information System, 2020). Institutional abbreviations are listed as in Sabaj (2019).

\section{RESULTS}

\section{Moenkhausia melogramma Eigenmann, 1908}

(Figs. 1-3; Tab. 1)

Moenkhausia melogrammus Eigenmann, 1908:102-103 [original description; type 
locality: "Tabatinga" (=Brazil, Amazonas State)].

Moenkhausia melogramma. -Eigenmann, 1910:437 [listed; adequacy of the specific epithet to the gender]. -Eigenmann, 1917:44; 67; 78-79; plates 6, 10 [diagnosis in key, redescription]. -Fowler, 1948:153 [listed]. -Géry, 1977:446 [diagnosis in key; allocation in the M. grandisquamis group]. -Axelrod et al., 1995:282 [photo in life]. -Lima et al., 2003:148 [listed]. -Arbeláez et al., 2004:102 [Colombia, Leticia, Quebrada La Arenosa]. -Galvis et al., 2006:221, 468 [short description, photo in life (pl. 43 b), ecological notes; Colombia, Amazonas, Leticia].

Moenkhausia melanogramma (spelling error). -Eigenmann, 1917:40 [comments about the third tooth on premaxilla].

Hemigrammus lunatus (not Durbin). -Ibarra, Stewart, 1989:369, 377 [in part; Ecuador, río Napo basin; abundance].

Hemigrammus cf. lunatus (not Durbin). -Galacatos et al., 1996:881, 889 [in part; Ecuador, río Napo basin; abundance]. -Galacatos et al., 2004:40-41, 44, 48 [in part; Ecuador, río Yasuni basin; abundance, habitat preference].

Moenkhausia sp. -Ota et al., 2019:345 [comparison with Hemigrammus changae; Ecuador, Sucumbíos, río Putamayo basin].

Diagnosis. Moenkhausia melogramma differs from all congeners, except M. collettii, M. copei, M. venerei Petroli, Azevedo-Santos, Benine, 2016, M. conspicua Soares, Bührnheim, 2016, and M. flava Britzke, Troy, Oliveira, Benine, 2018, by the presence of a broad dark longitudinal stripe across the eye ( $\nu$ s. absent) and a well-defined dark longitudinal stripe on the anal-fin base $v$ s. absent). Moenkhausia melogramma is promptly distinguished from M. collettii, M. copei, M. venerei, M. conspicua, and M. flava by having two humeral blotches ( $v$ s. a single humeral blotch). It differs from $M$. flava by the overall body coloration clear in live specimens ( $v$ s. pale-yellowish). Moenkhausia melogramma can be distinguished from $M$. collettii by having the first humeral blotch approximately triangular (vs. oval, horizontally elongated). It is further distinguished from M. conspicua, M. copei, and M. venerei by having a narrow, longitudinal, midlateral stripe, occupying one longitudinal series of scales ( $v$ s. longitudinal stripe wide, occupying two longitudinal series of scales).

Description. Morphometric data summarized in Tab. 1. Body compressed, moderately deep; greatest body depth anterior to dorsal-fin origin. Dorsal profile of head convex from tip of snout to anterior nostrils, straight to slightly concave from anterior nostrils to tip of supraoccipital spine. Dorsal profile of body moderately convex from tip of supraoccipital spine to dorsal-fin origin, posteroventrally slanted and straight from latter point to adipose fin, and slightly concave to straight along caudal peduncle. Ventral profile of body convex from anterior tip of lower jaw to pelvic fin; straight to slightly convex from pelvic-fin origin to anal-fin origin; posterodorsally slanted and straight along anal-fin base, and slightly to moderately concave along caudal peduncle.

Mouth terminal, isognathous. Two tooth rows in premaxilla: outer with three (42), four (211), or five* (22) tricuspid teeth; only specimens with five teeth have third tooth misaligned. Inner row with four (6), five*(265), or six (4) penta- to heptacuspid teeth. Maxilla with one (11), two *(139), three (104), or four (21) tri- to pentacuspid teeth. Dentary with anteriormost four ${ }^{\star}(270)$ or five (5) teeth penta- to heptacuspid, 

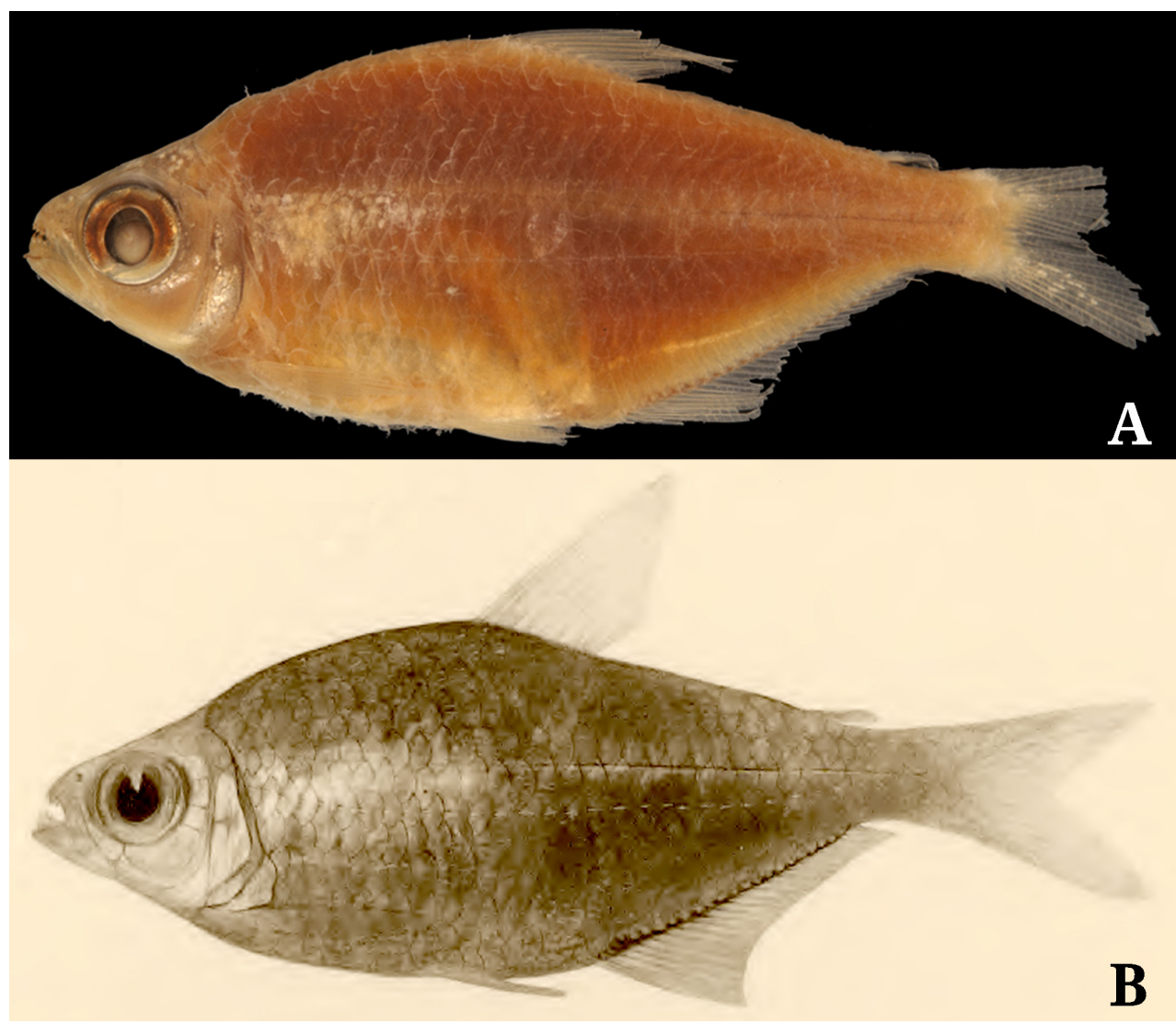

FIGURE 1 I Moenkhausia melogramma, holotype, MCZ 20285, 38.3 mm SL, Brazil, Amazonas, Tabatinga. A. recent photograph, available on MCZ website (all rights reserved); B. after Eigenmann, 1917 (pl. 6, fig. 1).

followed by middle-sized tricuspid tooth, and posteriormost five (3), six (1), 10 (1), or 11 (1) smaller, tricuspid or conical teeth. Central cusp of all teeth larger than lateral cusps.

Scales cycloid. Lateral line completely pored, slightly curved anteriorly, with 32 (34), $33(71), 34^{\star}(84) 35$ (30), or 36 (3) perforated scales. Six specimens with discontinuous lateral line, with solely one or two scales lacking pore (LBP 23758, 3, 33.9-36.0 mm SL; ZUEC 13213, 2, 30.6-41.5 mm SL; ZUEC 15479, 1, $33.1 \mathrm{~mm} \mathrm{SL).} \mathrm{Longitudinal}$ scale rows between dorsal-fin origin and lateral line five (135), six $^{\star}(137)$ or seven (2); longitudinal scale rows between lateral line and pelvic-fin origin three (6), four ${ }^{\star}$ (246) or five (21). Predorsal scale row with eight (4), nine (154) or 10 scales (105). Circumpeduncular scales 14 (221). Scale sheath along anal-fin base with up to seven small scales, in single row, overlying proximal portion of anteriormost anal-fin rays. Caudal fin scaled, scales covering proximal half of caudal-fin lobes.

Dorsal-fin rays ii (311), eight (7), nine ${ }^{\star}(302)$ or 10 (2). Dorsal-fin origin at midbody or slightly behind this point, slightly posterior to vertical through pelvic-fin origin. First unbranched ray shorter than second ray. Adipose fin at vertical through $12^{\text {th }}$ or $13^{\text {th }}$ caudal vertebrae. Pectoral-fin rays i (310), 10 (22), 11 (160), 12* (116) or 13 (12); tip of 
adpressed longest rays usually reaching pelvic-fin insertion. Pelvic-fin rays i (311), 6 (3), $7^{\star}(299)$ or 8 (9); tip of adpressed longest rays usually reaching anal-fin insertion. Analfin rays $\mathrm{iv}^{\star}(6), 20$ (11), 21 (53), 22 (73), 23 $3^{\star}(82), 24(55), 25$ (25) or 26 (6); anteriormost rays slightly longer, subsequent rays gradually decreasing in size. Principal caudal-fin rays i (278), eight (4) or nine $e^{\star}(274)+$ seven (2) or eight (276), $\mathrm{i}^{\star}(278)$. Dorsal procurrent caudal-fin rays 10 (3) or $11^{\star}(3)$ and ventral procurrent caudal-fin rays seven (2), eight (3) or nine ${ }^{\star}(1)$. Caudal fin forked; lobes similar in size.

Supraneurals four" (6), "I" or "Y" shaped with laminar bone almost along entire length. Precaudal vertebrae $15^{\star}(6)$; caudal vertebrae $18^{\star}(3)$ or $19(3)$; total vertebrae $33^{\star}(3)$ or $34(3)$. First gill arch with five (68), six (161) or seven (34) gill rakers on upper limb and 10 (59), 11 (151) or 12 (53) gill rakers on lower limb.

Color in alcohol. Overall ground color pale beige. Upper and lower lips, anterior portion of maxilla, snout, top of head and dorsal portion of opercle with scattered small dark chromatophores. Scales from two or three first longitudinal series of dorsal region posteriorly bordered by dark chromatophores, forming slightly reticulate pattern; scattered dark chromatophores concentrated along margins of myosepta of posterior half of lower portion of body, between lateral line and anal-fin base. Broad, dark

TABLE 1 I Morphometric data of Moenkhausia melogramma. Values for the holotype (MCZ 20825), range, and mean $\pm \mathrm{SD}$ (standard deviation).

\begin{tabular}{|c|c|c|c|c|}
\hline & holotype & $\mathbf{n}$ & range & mean \pm SD \\
\hline Standard length (mm) & 38.3 & 341 & $21.9-52.4$ & $33.9 \pm 5.7$ \\
\hline Head length (mm) & 10.0 & 341 & $6.2-14.0$ & $9.2 \pm 1.4$ \\
\hline \multicolumn{5}{|l|}{ Percentages of standard length } \\
\hline Depth at dorsal-fin origin & 39.9 & 341 & $28.5-45.0$ & $37.7 \pm 3.1$ \\
\hline Head length & 26.0 & 341 & $24.6-30.1$ & $27.2 \pm 1.1$ \\
\hline Head depth & 31.3 & 341 & $23.6-35.5$ & $29.9 \pm 2.0$ \\
\hline Dorsal-fin length & 24.1 & 305 & $29.9-40.5$ & $35.2 \pm 2.1$ \\
\hline Dorsal-fin base & & 340 & $13.4-19.0$ & $16.4 \pm 1.0$ \\
\hline Pectoral-fin length & 20.5 & 337 & $20.6-26.6$ & $23.3 \pm 1.0$ \\
\hline Pelvic-fin length & 14.9 & 336 & $16.9-23.5$ & $19.9 \pm 1.0$ \\
\hline Anal-fin length & 14.6 & 289 & $21.5-31.5$ & $26.1 \pm 1.9$ \\
\hline Anal-fin base & & 339 & $27.0-37.3$ & $32.7 \pm 2.2$ \\
\hline Caudal peduncle length & 11.0 & 338 & $5.3-12.9$ & $8.4 \pm 1.4$ \\
\hline Caudal peduncle depth & 9.6 & 338 & $6.9-12.0$ & $10.1 \pm 0.8$ \\
\hline Eye to dorsal-fin origin & 37.1 & 341 & $30.0-38.1$ & $34.3 \pm 1.4$ \\
\hline Snout to dorsal-fin origin & 51.2 & 340 & $45.1-53.2$ & $49.3 \pm 1.4$ \\
\hline Snout to pectoral-fin origin & 29.7 & 341 & $26.3-32.2$ & $29.0 \pm 1.1$ \\
\hline Snout to pelvic-fin origin & 46.4 & 340 & $42.9-63.9$ & $47.7 \pm 2.2$ \\
\hline Snout to anal-fin origin & 62.9 & 341 & $59.7-70.3$ & $64.8 \pm 2.2$ \\
\hline \multicolumn{5}{|l|}{ Percentages of head length } \\
\hline Snout length & 29.6 & 341 & $16.2-26.5$ & $20.7 \pm 1.8$ \\
\hline Upper jaw length & 42.3 & 340 & $35.7-47.9$ & $42.9 \pm 2.3$ \\
\hline Horizontal eye diameter & 40.5 & 341 & $34.7-49.9$ & $41.8 \pm 2.4$ \\
\hline Least interorbital width & 32.8 & 341 & $27.4-36.7$ & $32.7 \pm 1.6$ \\
\hline
\end{tabular}


longitudinal stripe crossing middle portion of eye, inconspicuous in specimens stored for long time in formalin. Two humeral blotches formed by brown chromatophores. First humeral blotch vertically elongated, slightly oblique, approximately triangular, roughly rounded in its upper portion and with irregular projections in its lower portion, extending vertically through two longitudinal scales series above lateral line and two series below it, more pigmented in the two series above lateral line. First humeral blotch followed posteriorly by clear area. Second humeral blotch inconspicuous, irregular, roughly oblique, comma-shaped, or a narrow vertical stripe, more concentrated above lateral line, with its limits well-defined (Figs. 2A, D, F) or progressively fading posteriorly as a longitudinal stripe (Figs. 2B, C, E). Few chromatophores scattered on region of hypural plate. Conspicuous longitudinal dark line along anal-fin base, formed by melanophores, covering base of anal-fin rays and proximal portion of interradial membranes. Dorsal fin with scattered dark chromatophores on interradial membranes. Adipose fin with few scattered dark chromatophores concentrated on anterior margin. Pectoral, pelvic, and caudal fins with few scattered dark chromatophores on interradial membranes (Fig. 2).

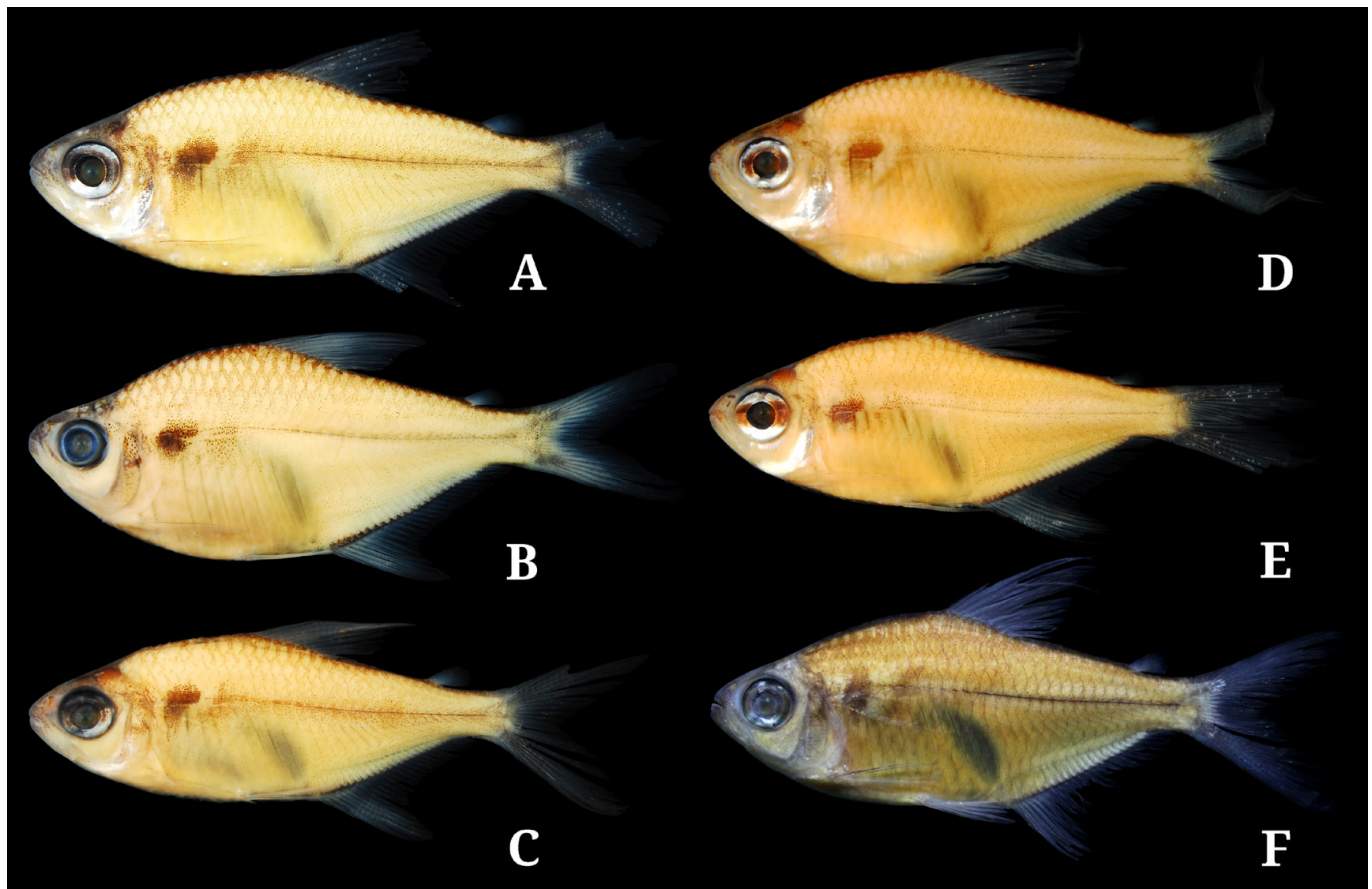

FIGURE 2 I Moenkhausia melogramma. A. ZUEC 14912, female, 39.9 mm SL, Brazil, Amazonas, Tabatinga, rio Solimões basin. B. ZUEC 15479, female, 38.1 mm SL, Brazil, Amazonas, Atalaia do Norte, rio Javari. C. MZUSP 122033, male, 33.2 mm SL, Brazil, Amazonas, Manicoré, rio Madeira basin. D. ZUEC 11327, female, 30.2 mm SL, Ecuador, Sucumbíos, río Gueppi, río Putumayo basin. E. MUSM 30440, male, 34.0 mm SL, Peru, Loreto, Maynas, Iquitos, quebrada San Lucas. F. MZUSP 106697, female, 43.2 mm SL, Peru, Madre de Dios, Mazuko, río Planchón. 
Color in life. Based on pictures of five specimens photographed in life (ZUEC 14944, ZUEC 15479; Fig. 3) and in the photo of one specimen provided by Galvis et al. (2006: 468, pl. 43 b). Overall color pattern clear, dorsum light grey, with an olive hue; top of head with metallic green-coppery color; midline with metallic green color, especially intense in area immediately before first humeral blotch. Lower portion of head and abdominal region clear, with silvery hue. Area immediately above anal fin slightly translucent. Fins mostly hyaline, yellowish pigmentation on anterior portion of dorsal, anal, and pelvic fins; tip of dorsal and anal fins whitish in some specimens. Black markings as in preserved specimens.

Sexual dimorphism. Mature males possess bony hooks on pelvic- and anal-fin rays or only on anal-fin rays. Pelvic fin with one small and slender bony hook per lepidotrichium segment, arranged along the middle portion of the unbranched ray and anteriormost first to second branched fin rays. Anal fin with one or two (rarely three) pairs or unpaired bony

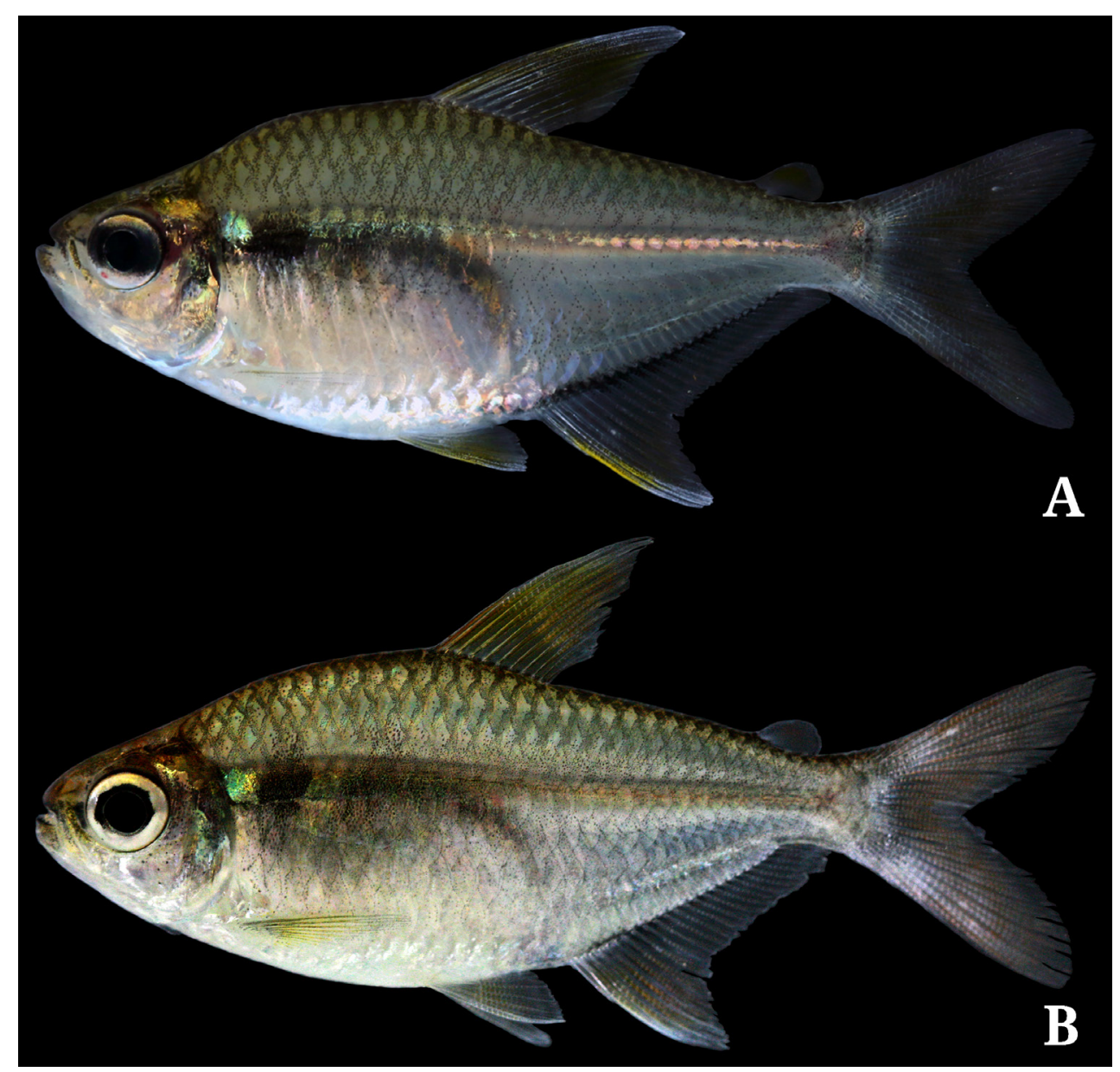

FIGURE 3 I Moenkhausia melogramma, immediately before preservation. A. ZUEC 15479, female, 37.6 mm SL, Brazil, Amazonas, Atalaia do Norte, rio Javari, igarapé do Adolfo. Photo: G. N. Salvador. B. ZUEC 13213, female, 41.5 mm SL, Brazil, Acre, Cruzeiro do Sul, igarapé Paleral, affluent of rio Moa. Photo: T. C. Pessali. 
hooks per lepidotrichium segment, arranged along distal half of last unbranched ray and from first to fourth branched rays, larger on middle portion of ray.

Geographic distribution. Moenkhausia melogramma is distributed across the western portion of the Amazon basin in Brazil, Colombia, Peru, and Ecuador, with its easternmost records for the rio Curuá and rio Tapajós basins on the lower Amazon basin (Fig. 4). Although we have examined only two lots of M. melogramma from Ecuador in the present study, a cursory examination of the material identified as Hemigrammus lunatus from both the Napo and Putumayo basins in Ecuador, deposited at FMNH and MEPN, by one of the authors (FCTL), showed it to belong mostly to M. melogramma (see also comments in Ota et al., 2019: 343). Records in the literature for the species, outside the range discussed above (Lasso et al., 2004) are discussed in the "Remarks" below.

Ecological notes. Moenkhausia melogramma was collected in moderate to relatively large clearwater terra firme streams, in the area of Tabatinga and Benjamin Constant,

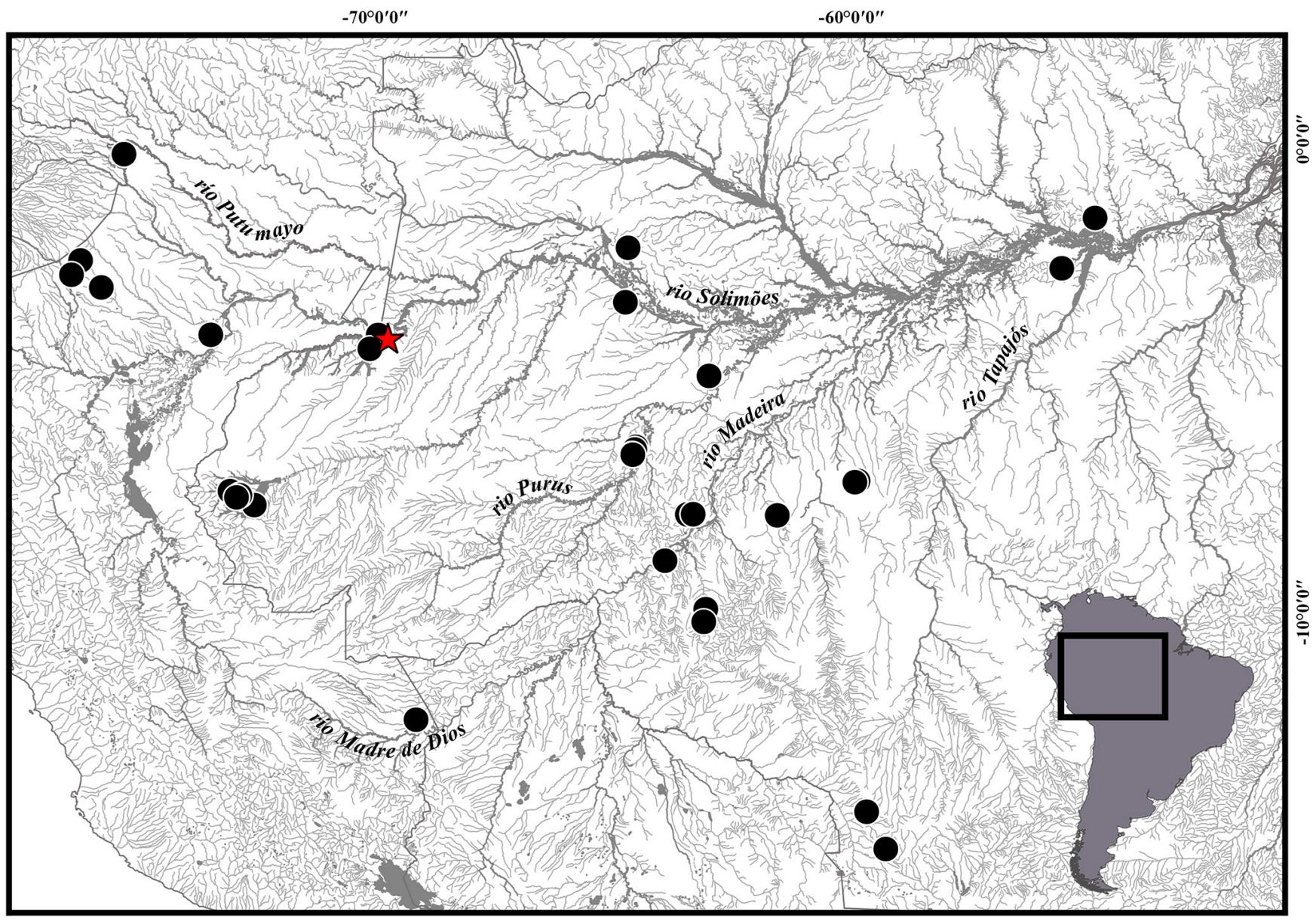

FIGURE 4 I Distribution of Moenkhausia melogramma in the western Amazon basin. Red star represents the type locality; black circles represent remaining known localities (one symbol may represent more than one lot). 
Amazon State, western Amazon basin of Brazil, and both black and slightly muddy water terra firme streams in the rio Juruá basin, Acre State (Flávio C. T. Lima, 20162017, pers. obs.). The species was collected in the same type of habitat in the region of Leticia, Colombia (Galvis et al., 2006: 221). Moenkhausia melogramma was considered to be ubiquitous in both piedmont (235-295 m asl) and lowland (below $220 \mathrm{~m}$ asl) areas in the río Napo basin (Galacatos et al., 1996; as Hemigrammus cf. lunatus, in part). Moenkhausia melogramma was collected in syntopy with M. collettii at the lago Amanã, rio Solimões basin (INPA 32161) and in a tributary of the middle rio Madeira (ZUEC 6736). The species was found to be an omnivore, ingesting terrestrial invertebrates and aquatic vegetation (Galvis et al., 2006: 221).

Conservation status. Moenkhausia melogramma is broadly distributed across the western Amazon basin, in relatively little disturbed areas, and it is considerably abundant at several sites. The species is known to occur in at least three Conservation Units: Canutama State Forest and Canutama Extractive Forest (rio Purus), both in Brazil, and at the Yasuní National Park in Ecuador. Due to broad geographical distribution, relatively high abundance, and relatively little impact from anthropogenic activities in the areas inhabited by the species, M. melogramma is herein categorized as Least Concern (LC), according to the International Union for Conservation of Nature (IUCN) categories and criteria (IUCN Standards and Petitions Subcommittee, 2017).

Remarks. Despite recorded in the literature, we were unable to confirm the occurrence of Moenkhausia melogramma from the río Orinoco basin (Lasso et al., 2004: 115). We consider this record as very likely the result of a misidentification of a similarlooking species occurring in that basin, such as Hemigrammus barrigonae Eigenmann, Henn, 1914 or M. collettii. The only previous records for the species in the literature that we were able to confirm were those by Arbeláez et al. (2004) and Galvis et al. (2006), from the region of Leticia in Departamento Amazonas, Colombia, from which the voucher material (not cited in the Material Examined) was cursorily examined by one of the authors (FCTL) during a visit to the ICN-MHN and IAvH-P collections.

Material examined. Holotype of Moenkhausia melogramma: MCZ 20825, $38.3 \mathrm{~mm}$ SL, Brazil, Amazonas State, Tabatinga, Sep-Oct 1865, D. Bourget (Thayer Expedition) (photos and radiographs only). Non-type specimens: Brazil: Rio Juruá basin: LBP 4112, 3, 26.2-31.4 mm SL, Acre, Mâncio Lima, rio Japiim, tributary of rio Moa, 7³4’28.8”S 72 55'24.9”W, 24 Oct 2006, C. Oliveira, R. C. Benine \& C. S. Silva; LBP 4133, 12, 21.9-28.5 mm SL, Acre, Mâncio Lima, rio Moa, 7²6’35.5”S 73³’33.5”W, 24 Oct 2006, C. Oliveira, R. C. Benine \& C. S. Silva; LBP 4148, 3, 31.9-38.8 mm SL, same data as LBP 4133; ZUEC 13414, 271, 23.5-41.5 mm SL, Acre, Mâncio Lima, igarapé Branco, 7³8’43”S 7252’55”W, 30 Sep 2016, T. C. Pessali, T. R. F. Jacó, T. L. Silva, A. Casas \& F. C. T. Lima; ZUEC 13314, 87, 20.8-31.6 mm SL, Mâncio Lima, Paraná de Pentecostes (trib. rio Moa), 7²8’2”S 7257’38”W, 29 Sep 2016, F. C. T. Lima, T. C. Pessali, T. R. F. Jacó \& T. L. Silva; ZUEC 13213, 36, 22.3-46.3 mm SL (2 c\&s 34.4-34.5 $\mathrm{mm}$ SL), Acre, Cruzeiro do Sul, igarapé Paleral, affluent of rio Moa, $7^{\circ} 31^{\prime} 48^{\prime \prime S}$ 7251’08”W, 29 Sep 2016, F. C. T. Lima, T. C. Pessali \& T. R. F. Jacó; ZUEC 13188, 189, 19.9-30.1 mm SL, Cruzeiro do Sul, lago Vermelho, rio Moa, 7³6’48”S 7248'10"W, 
23 Sep 2006, F. C. T. Lima, T. C. Pessali, T. R. F. Jacó, T. L. Silva \& R. Rubens; ZUEC 13221, 52, 26.6-35.8 mm SL, Acre, Cruzeiro do Sul, rio Croa, near BR-364, 744’16”S 72³2’59”W, 26 Sep 2016, F. C. T. Lima, T. C. Pessali, T. R. F. Jacó \& A. Casas. ZUEC 13555, 100, 23.2-30.4 mm SL, Cruzeiro do Sul, igarapé Preto, 7³6’15”S 7244’59”W, 24-26 Oct 2016, T. Jacó, T. Souza, R. Souza, J. Souza \& T. Nascimento; ZUEC 13102, 117, 21.5-28.9 mm SL, same locality as previous, 22 Sep 2016, F. C. T. Lima, T. C. Pessali, T. R. F. Jacó, A. Casas \& T. L. Silva; ZUEC 13819, 750, 24.5-39.9 mm SL, Amazonas, rio Gama, village of Gama, 7¹7’38”S 72³8’36”W, 24 Nov 2016, T. Jacó, A. Casas, J. Souza \& T. Souza; Amazonas: Rio Javari basin: ZUEC 15436, 2, 33.1-38.3 mm SL, Benjamin Constant, igarapé do Negão, road Benjamin Constant/Atalaia do Norte, 4²5'50"S 704'10"W, 17 Nov 2017, F. C. T. Lima, G. N. Salvador \& N. Flausino Jr; ZUEC 15479, 26, 31.9-39.3 mm SL, Atalaia do Norte, igarapé do Adolfo, road Benjamin Constant/Atalaia do Norte, 426’5”S 707'19”W, 11 Nov 2017, F. C. T. Lima, C. R. Moreira, G. N. Salvador \& N. Flausino Jr.; ZUEC 15625, 1, 35.7 mm SL, Atalaia do Norte, igarapé Branco, road Benjamin Constant/Atalaia do Norte, 425'1"S 70²'37'W, 9 Nov 2017, F. C. T. Lima, G. N. Salvador \& N. Flausino Jr. Rio Madeira basin: MZUSP 117596, 44, 16.0-44.3 mm SL (10, 27.8-44.3 mm SL), rio Juma, affluent of rio Aripuanã at BR-230 between Vila dos 180 and Apuí, 7¹2'43"S 5955'18”W, 22 Jun 2015, W. M. Ohara \& V. Abrahão; MZUSP 122033, 13, 26.0-35.1 mm SL, Manicoré, igarapé on side road S of Santo Antônio do Matupi district, km 180 of Transamazônica road (BR-230), 757’20.8”S 61³4’2.3”W, 3 Oct 2016, O. Oyakawa, W. Ohara, T. Teixeira \& M. Pastana; MZUSP 122525, 7, 21.8-35.4 mm SL (5, 28.9$35.4 \mathrm{~mm} \mathrm{SL}$ ), igarapé affluent of rio Juma, left to Transamazônica (BR-230), 7¹5’16”S $59^{\circ} 56^{\prime} 14.4$ "W, 8 Oct 2016, O. Oyakawa, W. Ohara, T. Teixeira \& M. Pastana; MZUSP 122544, 5, 27.6-32.9 mm SL, Apuí, rio Juma, igarapé affluent of rio Coruja, 7¹3’35.1”S 59 52'16.7'W, 8 Oct 2016, O. Oyakawa, W. Ohara, T. Teixeira \& M. Pastana. Rio Purus basin: INPA 23564, 1, 21.5 mm SL, Canutama, Canutama State Forest, rio Paisé, igarapé da Flor, 6³2’28.7”S 64³2’49.8”W, 27 May 2013, G. G. Barros; INPA 23577, 1, $25.1 \mathrm{~mm}$ SL, Canutama, Canutama State Forest, rio Paisé, 6³0'56.7”S 64³2’18.2”W, 28 Apr 2013, G. G. Barros; INPA 23774, 1, 20.3 mm SL, Canutama, Canutama State Forest, rio Paisé, 6³0'23.2”S 64³2'10.3”W, 11 May 2013, T. B. A. Couto; INPA 23801, 3, 23.9-26.2 mm SL, Canutama, Canutama Extractive Reserve, rio Paisé, 6 33’45.7”S 64³3’34.2”W, 11 May 2013, G. G. Barros; INPA 35017, 3, 26.4-30.1 mm SL, Canutama, igarapé at Canutama Extractive Reserve, 6³9’59”S 64³7’3”W, 2 Sep 2010, S. Arrolho \& R. Rosa; INPA 35028, 16, 22.6-28.9 mm SL, Canutama, igarapé at Canutama Extractive Reserve, 640’34”S 64³6’47”W, 2 Sep 2010, S. Arrolho \& R. Rosa; INPA 36442, 19, 21.3-29.0 mm SL, Canutama, igarapé at Canutama Extractive Reserve, 640'19”S 64³6'5”W, 2 Sep 2010, S. Arrolho \& R. Rosa; INPA 53275, 1, 30.1 mm SL, Tapauá, Turiaçu community, igarapé do Cemitério, 50'24”S 630'3”W, 12 Aug 2012, T. B. A. Couto; LBP 12017, 6, 26.3-31.7 mm SL, Lábrea, tributary of rio Purus, 756'6.6”S 6327'21.2”W, 24 Aug 2010, C. Oliveira, M. Alexandrou, G. J. C. Silva \& M. Taylor; MCP 54148, 3, 23.6-25.6 mm SL, Canutama, igarapé São João, tributary of rio Ipixuna, BR-319, about $60 \mathrm{~km}$ south of Humaitá, $7^{\circ} 55^{\prime} 53^{\prime}$ "S $63^{\circ} 20^{\prime} 3$ ” W, 28 Jul 2004, P. Buckup, P. Lehman, F. Lima \& J. Pezzi. Rio Solimões basin: INPA 32161, 24, 31.9-52.4 mm SL (1 c\&s 40.7 mm SL), Tefé, igarapé Baré, lago Amanã, $2^{\circ} 17 ’ 50$ ”S 6442’2”W, 6 Nov 2002, M. Catarino; ZUEC 15150, 6, 32.9-41.1 mm SL, 
Tefé, igarapé of Miriti (trib. rio Tefé), road of Agrovila, $3^{\circ} 26^{\prime} 55^{\prime}$ 'S $64^{\circ} 45^{\prime 2} 23^{\prime} \mathrm{W}, 30 \mathrm{Nov}$ 2017, F. C. T. Lima, G. N. Salvador \& N. Flausino Jr.; LBP 22682, 2, 34.7-37.9 mm SL; LBP 22683, 7, 30.7-37.9 mm SL, Tabatinga, igarapé Xingu, 4¹2’02.7”'S 6955’35.3”W, 16 Nov 2016, C. Oliveira, B. F. Melo, J. M. Marin \& G. Aricari; LBP 23758, 59, 31.642.1 mm SL (1 c\&s $34.2 \mathrm{~mm} \mathrm{SL}$ ), Tabatinga, igarapé Xingu, 4¹1’25.5”'S 6955’40.3”W, 17 Nov 2016, C. Oliveira, B. F. Melo, J. M. Marin \& G. Aricari; ZUEC 14944, 85, 24.8-42.3 mm SL (3 c\&s 27.2-35.6 mm SL); MCZ 173933, 10, 27.7-34.6 mm SL; LBP 26160, 5, 26.6-28.8 mm SL, Tabatinga, igarapé do Urumutum, 4¹2’34”S 6954’47”W, 21 Nov 2017, F. C. T. Lima, C. R. Moreira, G. N. Salvador \& N. Flausino Jr.; ZUEC 14912, 49, 22.9-39.8 mm SL, Tabatinga, same locality as previous lot, 3 May 2017, F. C. T. Lima, A. Acosta \& J. D. Bogotá-Gregory; ZUEC 14879, 13, 30.2-35.4 mm SL, Tabatinga, igarapé do Olivério, ramal do Urumutum, 4¹0'58"S 6954'22"W, 3 May 2017, F. C. T. Lima, A. Acosta \& J. D. Bogotá-Gregory; ZUEC 15331, 6, 38.5-41.2 mm, Tabatinga, stream at Ramal do Urumutum, 4¹0’3”S 6954'15”W, 20 Nov 2017, F. C. T. Lima, C. R. Moreira, G. N. Salvador \& N. Flausino Jr.; ZUEC 15068, 2, 30.2-33.7 mm SL, Benjamin Constant, igarapé Cajarizinho, 4²6’41”S 6959’56”W, 17 Nov 2017, F. C. T. Lima, C. R. Moreira, G. N. Salvador \& N. Flausino Jr. Mato Grosso: Rio Guaporé basin: MCP 39927, 19, 24.8-35.5 mm SL (12, 27.0-35.5 mm SL), Comodoro, stream affluent of rio Novo, at road BR-174, between Pontes e Lacerda and Comodoro, 14 '13'26”S 5941'27'W, 12 Jul 2004, V. Bertaco, F. Lima, J. P. Silva \& P. Lehmann; MCP 44561, 18, 25.1-36.1 mm SL (10, 27.3-36.1 mm SL), Pontes e Lacerda, rio Pindaituba, at road BR-174, between Pontes e Lacerda and Comodoro, $15^{\circ} 0$ '41"S 59¹7’18”W, 12 Jul 2004, V. Bertaco, F. Lima, J. P. Silva \& P. Lehmann. Pará: Rio Curuá basin: UFOPA 968, 12, 28.2-38.4 mm SL, Alenquer, tributary of rio Curuá, $1^{\circ} 39^{\prime} 57.5$ ”S 54 53’37.8”W, 6 Jan 2017, A. Silva, A. Canto, C. Silva, F. Ribeiro \& J. Souza. Rio Tapajós basin: ZUEC 12094, 11, 21.4-43.2 mm SL, Santarém, rio Mentaí, Cachoeirinha community, 243’49”S 55³5’34”W, 27 Nov 2015, F. C. T. Lima, B. B. Calegari, W. G. R. Crampton \& E. Cerdeira. Rondônia: Rio Guaporé basin: INPA 44330, 11, 25.0-38.6 (9, 30.7-38.6 mm SL), middle rio Cautário, 14 Jul 2003, G. Torrente-Vilara. Rio Jamari basin: NUP 20808, 1, 43.8 mm SL, Ariquemes, rio Jamari, 956'20.7”S 634'8.1"W, Jan 2016, J. R. Gonçalves; NUP 20809, 5, 30.0-38.0 mm SL, Ariquemes, rio Canaã, 10¹2’27.5”S 636’40.5”W, Dec 2016, J. R. Gonçalves; NUP 20811, 1, $38.5 \mathrm{~mm} \mathrm{SL}$, Ariquemes, rio Canaã, affluent of rio Jamari, 10¹2'27.5”S $63^{\circ}$ 6’40.5”W, Nov 2015, J. R. Gonçalves; NUP 20812, 3, 29.0-36.7 mm SL, Ariquemes, rio Itapoana, 957'22.8”S 635'45.7”W, Dec 2016, J. R. Gonçalves. ZUEC 6736, 5, 26.2-32.3 mm SL, Porto Velho, stream at Balneário Cachoeirinha, 854'50"S 635'ㄹ”'W, 12 Jul 2012, W. M. Ohara, T. H. S. Pires \& F. C. T. Lima. Colombia: Río Amazonas basin: LBP 22468, 1, $34.0 \mathrm{~mm}$ SL, Leticia, quebrada La Ponderosa, 4²'24.4”S 6956’53.4”W, 11 Nov 2016, C. Oliveira, B. F. Melo, J. M. Marin \& G. Aricari. Ecuador: Sucumbíos: Río Putumayo basin: ZUEC 11327, 15, 26.4-37.5 mm SL, río Gueppi, 0`18’59”'S 75¹7’13”W, 8-11 Aug 2000, R. Barriga \& A. Machado. Peru: Loreto: Río Amazonas basin: MUSM 30440, 37, 21.7-39.7 mm SL (20, 29.1 39.4 mm SL; 2 c\&s 33.8-34.7 mm SL), Maynas, Iquitos, quebrada San Lucas, 48'14.9”S 73²7’48.2"W, 15 Feb 1998, H. Ortega \& F. Chang; ZUEC 17118, 1, 34.7 mm SL, Iquitos, quebrada Lindero, road Iquitos/Nauta, 49'3"S 7328'23"W, 7 Jan 2004, W. G. R. Crampton, H. Ortega, R. E. Reis \& F. C. T. Lima. Río Madre de Dios basin: 
MZUSP 106697, 11, 21.2-44.6 mm SL (8, 21.2-44.6 mm SL), Mazuko, río Planchon, $36.3 \mathrm{~km}$ N of Puerto Maldonado, 12¹6’38”S 69 9'9”W, 28 Jul 2010, J. L. Birindelli, N. Lujan, D. Taphorn \& D. Brooks. Río Marañón basin: MUSM 25616, 8, 17.6-33.0 mm SL, Andoas, near río Corrientes, 2³3’53.7”S 76¹1’53.1”W, 18 Aug 2005, B. Rengifo; MUSM 38008, 9, 29.6-37.6 mm SL, Andoas, río Plantayacu, 38'8.4”S 7545’43.5”W, 18 Aug 2008, R. Quispe.

\section{DISCUSSION}

Eigenmann (1908) mentioned that the color pattern of Moenkhausia melogramma consisted in the presence of a line along the anal-fin base, a faint longitudinal midlateral dark stripe, and absence of blotches. Topotypes and additional material from other localities in western Amazon revealed that M. melogramma also possess other conspicuous pigmentation features, i.e., a broad dark stripe across the eye, and two humeral blotches, the first vertically elongated, and the second faint and inconspicuous. Although Eigenmann $(1908,1917)$ did not refer to the presence of the dark stripe across the eye, the examination of a picture of the holotype revealed that this feature is still discernible. The humeral blotches, however, cannot be in fact discerned in the holotype (Fig. 1). The holotype pigmentation is currently faded and judging from the retouched picture provided by Eigenmann (1917: pl. 6, fig. 1), it already was at the time of its description, so the lack of humeral blotches is considered as a preservation artifact.

Among congeners, Moenkhausia melogramma shares with M. collettii, M. copei, M. venerei, $M$. conspicua, and $M$. flava the presence of a broad longitudinal dark band across the eye, and a well-defined dark stripe on the anal-fin base (see Diagnosis). Among the aforementioned species, $M$. melogramma is more similar to $M$. flava due to the absence of a large longitudinal midlateral stripe, presence of six rows of scales between dorsalfin origin and lateral line, and four rows of scales between lateral line and pelvic-fin origin. However, M. melogramma differs from $M$. flava by the presence of two humeral blotches, the first very conspicuous ( $v$ s. only one inconspicuous humeral blotch), and by the general clear body color pattern in live specimens ( $v s$. pale-yellowish - see Britzke et al., 2018: fig. 4).

The presence of a broad stripe across the eye and a dark stripe along the anal-fin base are color features that Moenkhausia melogramma also shares with the Hemigrammus lunatus species-group (sensu Ota et al., 2014; 2019), which is composed by H. barrigonae, H. lunatus, H. machadoi Ota, Lima, Pavanelli, 2014, H. ulreyi (Boulenger, 1895), and the recently described H. changae Ota, Lima, Hidalgo, 2019. Moenkhausia melogramma can be distinguished from all aforementioned species by having a complete lateral line (vs. incomplete in H. lunatus, H. machadoi, H. ulreyi, and H. changae, discontinuous in some $H$. barrigonae specimens), and by the presence of two humeral blotches ( $v s$. one, with the exception of $H$. machadoi that can eventually present a second faded humeral blotch). It is further distinguished from H. changae and H. lunatus by having a relatively broad dark stripe on all extension of anal-fin base ( $v s$. narrow dark stripe). Moenkhausia melogramma can be differentiated from $H$. barrigonae and $H$. ulreyi by having a very narrow and faint longitudinal midlateral stripe ( $v$ s. wide and conspicuous midlateral stripe in H. barrigonae and H. ulreyi). 
Additionally, the species differs from Hemigrammus machadoi, the most similar noncongener species, by having a higher number of precaudal (15 vs. 13-14) and lower number of caudal vertebrae (18-19 vs. 21), 5-8 (mode 6) gill rakers on upper limb and 9-13 (mode 11) gill rakers on lower limb (vs. 4-5, mode 5 and 9-10, mode 10, respectively) of the first branchial arch. Furthermore, M. melogramma is larger (reaching $50 \mathrm{~mm} \mathrm{SL}$ ), whereas $H$. machadoi is smaller (never surpassing $35 \mathrm{~mm} \mathrm{SL}$ ).

Ota et al. (2014), when discussing the Hemigrammus lunatus species-group, highlighted the similarity between those species with $M$. collettii and congeners with similar color pattern (i.e., a broad stripe across the eye and a dark line along anal-fin basin), that it might indicate a close relationship between the latter species and this species-group. This putative monophyletic group had been partially supported by molecular hypotheses, that recovered a clade composed by the aforementioned species plus $M$. hemigrammoides Géry, 1965 and Aphyodite grammica Eigenmann, 1912 (Mariguela et al., 2013; Britzke et al., 2018; Mirande, 2019).

In fact, as argued by Britzke et al. (2018), the putative close relationship between M. collettii, M. copei, and M. flava with H. unilineatus Gill, 1858, the type species of Hemigrammus, highlights the weakness of the degree of lateral line perforation as a diagnostic character to distinguish both genera. As earlier remarked by Weitzman, Fink (1983), this character clearly is highly homoplastic, with non-homologous reductions occurring many times within Characidae. The presence of the discontinuous lateral line is a rare condition in M. melogramma, and it also occurs in some specimens of M. collettii and $M$. copei, even though the pores and canals extend to caudal fin in all specimens analyzed (Isabel M. Soares, 2020, pers. obs.).

A phylogenetic analysis including the species of Hemigrammus lunatus species-group and the similar-looking species of Moenkhausia (i.e., M. collettii, M. copei, M. conspicua, M. flava, M. melogramma, and M. venerei) is currently being conducted by the first author to test the relationships within this putative monophyletic clade and its relationships with the remaining Characidae.

Comparative material examined. Hemigrammus barrigonae: Colombia: INPA 49986, 25, 22.2-37.3 mm SL (1 c\&s $31.8 \mathrm{~mm} \mathrm{SL).} \mathrm{Hemigrammus} \mathrm{changae:} \mathrm{see} \mathrm{Ota} \mathrm{et}$ al. (2019). Hemigrammus lunatus: see Ota et al. (2019). Hemigrammus machadoi: Brazil: MZUSP 115629, 11, 29.7-38.2 mm SL. Hemigrammus ulreyi: Brazil: LBP 7604, 13, 25.2-33.6 mm SL. Moenkhausia collettii: Brazil: INPA 52697, 5, 33.5-45,9 mm SL (1c\&s $41.8 \mathrm{~mm} \mathrm{SL}$ ). Colombia: ANSP 128697, 20, 34.2-48.2 mm SL (1 c\&s $43.3 \mathrm{~mm}$ SL). Moenkhausia conspicua: see Soares, Bührnheim (2016). Moenkhausia copei: Brazil: UFOPA 144, 2, 28.8-32.0 mm SL; UFOPA 719, 2, 29.3-29.8 mm SL. Moenkhausia flava: Brazil: MZUSP 123719, 33.6 mm SL, holotype; LBP 9031, 10, 20.0-35.4 mm SL, paratypes; LBP 18414, 15, 18.6-37.8 mm SL; MZUSP 123720, 10, 26.6-34.3 mm SL. Moenkhausia venerei: Brazil: NUP 8104, 10, 23.7-28.6 mm SL.

\section{ACKNOWLEDGMENTS}

The authors are grateful to Hernán Ortega, Max Hidalgo, and Nicol Faustino (MUSM), Cláudio Oliveira (LBP), André Canto (UFOPA), Alessio Datovo (MZUSP), Lúcia 
H. Rapp Py-Daniel and Cárlison Oliveira (INPA), Carlos Lucena (MCP-PUCRS), Ramiro Barriga (MEPN), Caleb MacMahan, Kevin Swagel, and Susan Mochel (FMNH), José Iván Mojica, Henry Agudelo, and Gabriela Serrato (ICN-MHN), Carlos DoNascimiento, Juan Gabriel Albornoz-Garzón, and Alejandro MéndezLópez (IAvH-P) for assistance during visits to their respective collections and/or loan or donation of material examined in this study. Karsten Hartel and Andrew Williston (MCZ) provided a photo of the teeth of the holotype of Moenkhausia melogramma. Tiago C. Pessali (PUC Minas) and G. N. Salvador (UFPA) provided a photo of recently preserved specimen. Gabriel Deprá read an early draft of the present contribution and made useful comments and suggestions. We also thank comments and corrections made by Manoela M. Marinho (UFPB) and Renata R. Ota (NUP) that greatly improved the quality of the manuscript. This study was financed in part by the CAPES (RPO; grants \#12002011001P7), FAPESP (FCTL; grants \# 2011/51532-7 and 2013/20936-0) and CNPq (RCB; grants \#307975/2019-3).

\section{REFERENCES}

- Arbeláez F, Gálvis G, Mojica JI, Duque S. Composition and richness of the ichthyofauna in a terra firme forest stream of the Colombian Amazonia. Amazoniana. 2004; 18(1/2):95-107.

- Axelrod HR, Burgess WE, Pronek N, Walls JG. Dr. Axelrod's atlas of freshwater aquarium fishes. Neptune City: T.F.H. Publications; 1995.

- Britzke R, Troy WP, Oliveira C, Benine RC. Description of a new species of Moenkhausia (Characiformes: Characidae) from the upper Paraguay basin, Central Brazil, with comments on its phylogenetic relationships. Neotrop Ichthyol. 2018; 16(2):e170086. http://dx.doi. org/10.1590/1982-0224-20170086

- Eigenmann CH. Preliminary descriptions of new genera and species of tetragonopterid characins (Zoölogical Results of the Thayer Brazilian expedition). Bull Mus Comp Zool. 1908; 52:91-106.

- Eigenmann CH. Catalogue of the freshwater fishes of tropical and south temperate America. Reports of the Princeton University expeditions to Patagonia 1896-1899. Zoology. 1910; 3(4):375-511.

- Eigenmann CH. The American Characidae. Mem Mus Comp Zool. 1917; 43(1):1-102, pt. 1.
- Fink WL, Weitzman SH. The so-called Cheirodontin fishes of Central America with descriptions of two new species (Pisces: Characidae). Washington: Smithsonian Institution Press; 1974. (Smithsonian Contributions to Zoology; No 172).

- Fowler HW. Os peixes de água doce do Brasil. Arq Zool(São Paulo). 1948; 6(112):1-204.

- Fricke R, Eschmeyer WN, Van der Laan R. Eschmeyer's catalog of fishes: genera, species, references [Internet]. San Francisco: California Academy of Sciences; 2020. Available from: http:// researcharchive.calacademy.org/research/ ichthyology/catalog/fishcatmain.asp

- Galacatos K, Barriga-Salazar R, Stewart DJ. Seasonal and habitat influences on fish communities within the lower Yasuni River basin of the Ecuadorian Amazon. Environ Biol Fish. 2004; 71:33-51. https://doi.org/10.1023/ B:EBFI.0000043156.69324.94

- Galacatos K, Stewart DJ, Ibarra M. Fish community patterns of lagoons and associated tributaries in the Ecuadorian Amazon. Copeia. 1996; 1996(4):875-94. Available from: https://www.jstor.org/ stable/1447650 
- Galvis G, Mojica JI, Duque SR, Castellanos C, Sánchez-Duarte P, Arce M, Gutiérrez Á, Jiménez LF, Santos M, Vejarano S, Arbeláez F, Prieto E, Leiva M. Peces del medio Amazonas. Región de Leticia. Bogotá: Conservación Internacional; 2006. (Serie de Guías Tropicales de Campo 5).

- Géry J. Characoids of the world. Neptune City: T.F.H. Publications; 1977.

- Ibarra M, Stewart DJ. Longitudinal zonation of sandy beach fishes in the Napo River basin, eastern Ecuador. Copeia. 1989; 1989(2):364-81. Available from: https:// www.jstor.org/stable/1445433

- International Union for Conservation of Nature (IUCN). Standards and Petitions Subcommittee. Guidelines for using the IUCN Red List Categories and Criteria. Version 13 [Internet]. Gland; 2017. Available from: http://cmsdocs. s3.amazonaws.com/RedListGuidelines.pdf

- Lasso CA, Mojica JI, Usma JS, MaldonadoOcampo JA, DoNascimiento C, Taphorn DC, Provenzano F, Lasso-Alcalá OM, Galvis G, Vásquez L, Lugo M, MachadoAllison A, Royero R, Suárez C, OrtegaLara A. Peces de la cuenca del río Orinoco. Parte I: lista de especies y distribución por subcuencas. Biota Colomb. 2004; 5(2):95158.

- Lima FCT, Malabarba LR, Buckup PA, Silva JFP, Vari RP, Harold A, Benine RC, Oyakawa OT, Pavanelli CS, Menezes NA, Lucena CAS, Malabarba MCSL, Lucena ZMS, Reis RE, Langeani F, Casatti L, Bertaco VA, Moreira CR, Lucinda PHF. Genera Incertae Sedis in Characidae. In: Reis RE, Kullander SO, Ferraris CJ, Jr., editors. Check List of the Freshwater Fishes of South and Central America. Porto Alegre: Edipucrs; 2003. p.106-69.

- Mariguela TC, Benine RC, Abe KT, Avelino GS, Oliveira C. Molecular phylogeny of Moenkhausia (Characidae) inferred from mitochondrial and nuclear DNA evidence. J Zoolog Syst Evol Res. 2013; 51(4):327-32. http://dx.doi.org/10.1111/ jzs.12025

- Menezes NA, Weitzman SH. Two new species of Mimagoniates (Teleostei: Characidae: Glandulocaudinae), their phylogeny and biogeography and a key to the glandulocaudin fishes of Brazil and Paraguay. Proc Biol Soc Wash. 1990; 103(2):380-426.
- Mirande JM. Phylogeny of the family Characidae (Teleostei: Characiformes): from characters to taxonomy. Neotrop Ichthyol. 2010; 8(3):385-568. http://dx.doi. org/10.1590/S1679-62252010000300001

- Mirande JM. Morphology, molecules and the phylogeny of Characidae (Teleostei, Characiformes). Cladistics. 2019; 35(3):282300. https://doi.org/10.1111/cla.12345

- Oliveira C, Avelino GS, Abe KT, Mariguela TC, Benine RC, Ortí G, Vari RP, Castro RMC. Phylogenetic relationships within the speciose family Characidae (Teleostei: Ostariophysi: Characiformes) based on multilocus analysis and extensive ingroup sampling. BMC Evol Biol. 2011; 11(275):1-25. https:// doi.org/10.1186/1471-2148-11-275

- Ota RP, Lima FCT, Pavanelli CS. A new species of Hemigrammus Gill, 1858 (Characiformes: Characidae) from the rio Madeira and rio Paraguai basins, with redescription of $H$. lunatus. Neotrop Ichthyol. 2014; 12(2):265-79. http://dx.doi. org/10.1590/1982-0224-20130176

- Ota RP, Lima FCT, Hidalgo MH. Description of a new Hemigrammus Gill (Characiformes: Characidae) from the río Madeira basin in Peru and Bolivia. Zootaxa. 2019; 4577(2):335-47. http:// dx.doi.org/10.11646/zootaxa.4577.2.6

- Qgis.org. QGIS Geographic Information System. Open Source Geospatial Foundation Project. Available from: https:// www.qgis.org/

- Sabaj MH. Standard symbolic codes for institutional resource collections in herpetology and ichthyology: an Online Reference [Internet]. Washington: American Society of Ichthyologists and Herpetologists. Available from: https://asih. org/standard-symbolic-codes

- Soares IM, Bastos DA, Lima FCT, Rapp Py-Daniel LH. A new species of Moenkhausia Eigenmann, 1903 (Characiformes, Characidae) from the upper rio Negro basin, Brazil. Copeia. 2019; 107(2):232-38. https://doi.org/10.1643/CI18-149

- Soares IM, Bührnheim CM. A new species of Moenkhausia Eigenmann, 1903 (Characiformes: Characidae) from Amazon basin, Brazil. Zootaxa. 2016; 4208(4):392-400. http://dx.doi.org/10.11646/ zootaxa.4208.4.6 
- Soares NC, Benine RC. Moenkhausia restricta, a new species from the upper Rio Negro, Amazon basin, northwestern Brazil (Characiformes: Characidae). Zootaxa. 2019; 4700(4):487-93. http://dx.doi. org/10.11646/zootaxa.4700.4.7

- Taylor WR, Van Dyke GC. Revised procedures for staining and clearing small fishes and other vertebrates for bone and cartilage study. Cybium. 1985; 9(2):107-19.

- Terán GE, Benitez MF, Mirande JM. Opening the Trojan horse: phylogeny of Astyanax, two new genera and resurrection of Psalidodon (Teleostei: Characidae). Zool J Linnean Soc. 2020; 1-18. https://doi.org/10.1093/zoolinnean/ zlaa019
- Weitzman SH, Fink WL. Relationships of the neon tetras, a group of South American freshwater fishes (Teleostei, Characidae), with comments on the phylogeny of New World characiforms. Bull Mus Comp Zool. 1983; 150(6):339-95.

\section{Neotropical |chthyology}

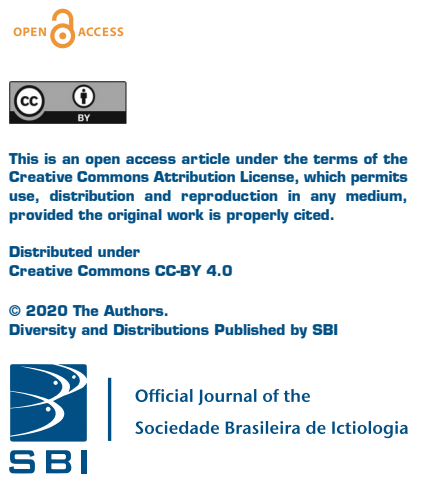

\section{AUTHOR'S CONTRIBUTION (a)}

Isabel Mattos Soares: Conceptualization, Data curation, Formal analysis, Investigation, Methodology,

Project administration, Writing-original draft, Writing-review \& editing.

Rafaela Priscila Ota: Conceptualization, Data curation, Formal analysis, Investigation, Methodology,

Project administration, Supervision, Writing-original draft, Writing-review \& editing.

Flávio César Thadeo de Lima: Conceptualization, Data curation, Formal analysis, Investigation,

Methodology, Writing-original draft, Writing-review \& editing.

Ricardo Cardoso Benine: Conceptualization, Project administration, Funding acquisition, Supervision,

Writing-original draft, Writing-review \& editing.

\section{ETHICAL STATEMENT}

Not applicable.

\section{COMPETING INTERESTS}

The authors declare no competing interests.

\section{HOW TO CITE THIS ARTICLE}

- Soares IM, Ota RP, Lima FCT, Benine RC. Redescription of Moenkhausia melogramma (Characiformes: Characidae), a poorly known tetra from the western Amazon basin. Neotrop Ichthyol. 2020; 18(3):e200025. https://doi.org/10.1590/1982-0224-2020-0025 